\title{
INTELECTUAIS E UNIVERSIDADE PERCEPÇÕES SOCIOLÓGICAS A PARTIR DE UMA EXPERIÊNCIA PEDAGÓGICA
}

\author{
INTELLECTUALS AND UNIVERSITY \\ SOCIOLOGICAL PERCEPTIONS FROM A PEDAGOGICAL EXPERIENCE
}

\section{INTELECTUALES Y UNIVERSIDADES \\ PERCEPCIONES SOCIOLÓGICAS A PARTIR DE UNA EXPERIENCIA PEDAGÓGICA}

\section{Antonio Carlos Dias Junior ${ }^{1}$}

\begin{abstract}
RESUMO: O artigo discute a temática dos intelectuais e sua relação com a sociedade a partir do locus privilegiado em que atuam: a universidade. No âmbito da disciplina de licenciatura oferecida pela Unicamp, Tópicos Especiais em Ciências Sociais Aplicadas à Educação - EL 142 (sob minha responsabilidade no primeiro semestre de 2015) e tendo em vista a inquietação inicial acima citada, foi proposto como tema para o curso a reflexão sobre a formação das universidades modernas e, conjuntamente, a atuação do intelectual em seus quadros. Problematizouse, com efeito, a função ou o papel que os intelectuais exercem nos dias atuais e a validade do status conferido a esses sujeitos como intérpretes privilegiados da realidade. O diálogo com a bibliografia específica sugerida para a disciplina, a percepção dos estudantes em relação à temática proposta - obtida por meio das discussões em sala e pela avaliação do curso, bem como minha própria autoanálise reflexiva da experiência no decorrer do semestre, configuram as balizas nas quais o artigo se assenta.
\end{abstract}

PALAVRAS-CHAVE: Intelectuais. Universidade. Ensino.

ABSTRACT: The article discusses the thematic of intellectuals and their relation with the society from privileged locus in which they actuate: the university. In the ambit of the subject matter offered by Unicamp, Especial Topics in Social Sciences Applied to Education - EL 142 (under my responsibility in the first semester of 2015) and considering the initial inquietude above mentioned, was proposed like theme to the course the reflexion about the formation of the modern universities, combined, the performance of the intellectuals in their boards. Problematize, with effect, the function or the paper those intellectuals exercises at this moment and the validity of status imputed to these individuals like privileged interpreters of reality. The dialogue with the specific bibliography suggested to the discipline, the perception of the students with regard to thematic proposed - obtained through discussions at class and by course's evaluation, also my own reflexive auto analysis of experience occur the semester, configures the marks in which the article seats.

KEYWORDS: Intellectuals. University. Teaching.

RESUMEN: El artículo discute la temática de los intelectuales y su relación con la sociedad del locus privilegiado donde actúan: la universidad. En el ámbito de la asignatura de licenciatura ofrecida por Unicamp, Tópicos Especiales en Ciencias Sociales Aplicadas a la Educación - EL 142 (bajo mi responsabilidad en el primer semestre de 2015) y en vista de la inquietud inicial anteriormente citada, fue propuesto como tema para el curso la reflexión sobre la formación de las universidades modernas y, conjuntamente, la actuación del intelectual en sus cuadros.

\footnotetext{
${ }^{1}$ Doutor em Sociologia pela Universidade Estadual de Campinas (2013). Professor do Departamento de Ciências Sociais na Educação da Faculdade de Educação da UNICAMP e atua no Programa de Pós-graduação em Educação pela mesma universidade. E-mail: acdiasjr@gmail.com.

Recebido em: 07/08/2015 - Aceito em: 17/11/2015.
}

\begin{tabular}{l|l|l|l|l|l|l} 
(C) ETD - Educ. Temat. Digit. & Campinas, SP & v.17 & n.3 & p.673 & set./dez.2015 & ISSN 1676-2592
\end{tabular}


Se problematizó, en efecto, la función o el papel que los intelectuales ejercen en los días actuales y la validez del status atribuidos a estos sujetos como intérpretes privilegiados de la realidad. El diálogo con la bibliografía específica sugerida para la presente asignatura, la percepción de los estudiantes con relación a la temática propuesta -obtenida a través de las discusiones en clase y por la evaluación del curso, así como mi propio autoanálisis reflexivo de la experiencia en el transcurrir del semestre, configuran los límites en los cuales se apoya el artículo.

PALABRAS CLAVE: Intelectuales. Universidad. Enseñanza.

\section{INTRODUÇÃO}

Uma das questões mais antigas e mais importantes no que diz respeito à atividade intelectual se refere à função, ou ao papel, exercido por aqueles que, por iniciativa ou delegação, se arvoram como intérpretes ou paladinos demiúrgicos da realidade social. Sujeitos que, no contexto histórico específico no qual emergiram como figuras públicas relevantes (estertores do século XIX) na qualidade de párias que se metiam naquilo que não lhes dizia respeito (segundo a célebre conjectura sartriana, os intelectuais gozaram desde então de prestígio incomum, mas com data de validade estabelecida: a atual sociedade informacional fluída, fragmentada e multifacetada, que parece colocar à margem toda e qualquer tentativa elaborada, global ou parcial, de intelecção ou de visão de mundo.

O intelectual, a quem se atribuiu a tarefa de organizar a cultura, de servir de guia espiritual, de intérprete ou mesmo de mediador da massa inculta em face das suas potencialidades, vê-se atualmente em um beco sem saída. Haveria ainda espaço para o intelectual-total, para aquela figura pública que, como Jean-Paul Sartre, encarnava a consciência de uma época? O intelectual teria ainda um papel a cumprir ou as metamorfoses derivadas dos virulentos embates político-ideológicos que cindiram e polarizaram o mundo no século XX tornaram-no figura supérflua? Se a resposta for positiva, cabem outras perguntas: quem atribuiu tal tarefa a esses indivíduos? Os intelectuais são (ou foram) figuras realmente importantes (tal qual sempre se acreditou) ou não passam de meras ficções? No caso de a resposta configurar uma negativa, estaria o intelectual em silêncio ou estaria ele morto?

Outro aspecto essencial ligado à produção intelectual diz respeito à universidade como o locus específico no qual essa atividade prioritariamente acontece, ou deveria acontecer. Desde a sua constituição histórica no medievo, a partir do século IX, essa instituição congregou, através dos tempos, as diversas elites intelectuais, de maneira tal que, até pouco tempo, fazia-se quase impossível dissociar uma imagem da outra. Repito: até pouco tempo. Em minha experiência como docente no Ensino Superior, tanto no ensino público quanto no privado, amadureci a percepção segundo a qual, para as novas gerações de estudantes, a universidade representa, na maioria das vezes, apenas um estágio para o mercado de trabalho, ou a preparação para ele. Poucas vezes, mesmo lecionando em cursos na área das ciências humanas, tive a sensação de que os estudantes experimentavam a universidade (ou a percebiam) como um local no qual a atividade intelectual (no sentido amplo acima aludido) acontecia.

\begin{tabular}{l|l|l|l|l|l|l|} 
(C) ETD - Educ. Temat. Digit. & Campinas, SP & v.17 & n.3 & p.673 & set./dez.2015 & ISSN 1676-2592 \\
\hline
\end{tabular}


Obviamente, ao lecionar para turmas de graduação da Unicamp, notava que a visão sobre a universidade, em suas múltiplas dimensões como espaço público, se fazia de alguma forma presente nos alunos e alunas que se matriculavam em minhas disciplinas. Isso se tornava perceptível não somente pela bagagem cultural diferenciada que os estudantes traziam consigo, fruto das oportunidades e possibilidades que tiveram e que foram negadas à maior parte dos estudantes das faculdades particulares, mas também porque eu gozava de liberdade curricular para levantar questões mais reflexivas durante os cursos que ministrava (algo cada vez mais improvável nas faculdades particulares, cujo conhecimento é transmitido quase sempre de forma pasteurizada), e as discutia em sala. Fui acalentando aos poucos, com efeito, o desejo de tornar a temática dos intelectuais e de sua relação com a universidade o tema de um curso regular.

Preocupava-me, como ainda me preocupa, a percepção de que as novas gerações de estudantes não se ocupam com a salutar reflexão sobre a atividade intelectual, ainda que compreenda que esse é apenas mais um dos muitos reflexos das relações sociais na contemporaneidade, cuja tônica repousa no culto ao efêmero e na multiplicidade de interesses instantâneos e cambiáveis. Com isso em mente, e tendo em vista que tal temática em específico aparece apenas ocasionalmente no currículo dos cursos de graduação (mesmo na área de ciências humanas), essa lacuna tornava-se quase que "natural": assim como ler um livro de orelha a orelha se tornou prática incomum entre as novas gerações, posto que não segue a lógica do click e demanda concentração e introspecção, também o tema referente aos intelectuais, ou qualquer outro assunto que não dissesse respeito imediato ao currículo de cada curso em específico, seria negligenciado, ou, em outras palavras, não representaria uma questão.

No fundo, o que realmente me inquietava era o fato de esses estudantes, que frequentam uma universidade pública, não terem mais a referência (nem mesmo histórica) dessa instituição como local par excellence da elucubração intelectual; de a universidade pública no Brasil não configurar, em suas consciências, como nada (ou pouco) além de uma instituição como outra qualquer, à diferença de nesta se poder obter um diploma ou, no melhor dos casos, instrução além de convivências diversas com colegas e professores por um determinado período. Não compartilho, evidententemente, da ideia presunçosa e elitista segundo a qual cabe à universidade um status diferenciado, ou do princípio de que a atividade intelectual emana exclusivamente da academia, ficando aos seus muros restrita, como em uma torre de marfim. Ressalte-se, desde já, que tal percepção, a meu juízo bastante equivocada, foi problematizada e questionada em muitos aspectos no decorrer da disciplina.

No segundo semestre de 2015, na qualidade de professor da Faculdade de Educação da Unicamp, coube a mim a responsabilidade de ministrar (para duas turmas, uma vespertina e outra noturna) a disciplina de licenciatura EL 142 - Tópicos Especiais em Ciências Sociais Aplicadas à Educação, que faz parte do núcleo de disciplinas que os estudantes das carreiras que oferecem a modalidade licenciatura devem cumprir. Por se tratar de um curso cuja ementa é abrangente e que é frequentado por alunos e alunas das três grandes áreas do conhecimento, julguei que seria o momento adequado para tratar da temática dos intelectuais e de sua relação

\begin{tabular}{l|l|l|l|l|l|l|} 
(C) ETD - Educ. Temat. Digit. & Campinas, SP & v.17 & n.3 & p.673 & set./dez.2015 & ISSN 1676-2592 \\
\hline
\end{tabular}


com a universidade. Não tinha em mente, à época, construir um relato de caso a partir dessa experiência, mas o andamento das atividades, bem com as discussões realizadas em sala e seus desdobramentos, encorajaram-me a torná-la pública, ${ }^{2}$ como parte da obrigação permanente de autorreflexão (no sentido que Pierre Bourdieu dá ao termo) a que todo intelectual deve se impor.

\section{DILEMAS DO INTELECTUAL}

O intelectual, diz, é (ou deveria ser) sempre do contra. O inconformismo configuraria a natureza de sua atuação e responderia pela sua própria essência ontológica. No entanto, o caráter cético e inconformista que deriva da índole do intelectual, o que hoje entendemos como uma virtude a ser cultivada, nasce rodeado de preconceitos. O neologismo intellectuel debuta no contexto francês do Affaire Dreyfus, remetendo-se àqueles que, como Émile Zola, denunciavam algo que fugia de sua esfera de competência. Ser um intelectual representava antes a especulação vazia e despropositada por parte daqueles que não tinham mais o que fazer que a crítica ao poder e seus desmandos. O sacerdote, o sábio, o clérigo, o philosophe, o literato, enfim, as gens de lettres - que marcaram de forma indelével a história da humanidade, ter-seiam convertido em abelhudos causadores de polêmica, em falsos profetas contaminados pelo vírus da banalidade frívola da vida e da política citadinas. Na célebre acepção de Julien Benda, seriam todos traidores.

O prestígio atribuído a esses causadores de contenta logo seria, contudo, estabelecido. Os próprios desdobramentos do Affaire Dreyfus, que reabilitariam a imagem do oficial judeu Alfred Dreyfus, injustamente condenado por crime de alta traição, enfatizariam de maneira doravante inconteste a importância da ação do intelectual. Zola, em sua carta J'accuse endereçada ao presidente da república francesa e publicada no jornal L'Aurore em janeiro de 1898, exige a pronta revisão do processo fraudulento que inocentou o verdadeiro culpado, o comandante Esterházy. O apoio de ilustres escritores a Zola, como Anatole France e Marcel Proust - ao que entrou para a história como o "Manifesto dos Intelectuais", forneceu a baliza pela qual o intelectual orientaria sua ação: o discurso universalista da verdade e da justiça.

Com efeito, por meio da ação de um grupo de indivíduos notórios que, não sendo políticos de ofício, tomaram posição como homens de letras e combateram a razão do Estado em nome de razões não específicas, fortificou-se a imagem do intelectual como aquele que toma para si a incumbência de denunciar (ou dirimir) as arbitrariedades e injustiças a que muitos grupos ou indivíduos isoladamente são sujeitados. Acontece que aquele grupo de iluminados jamais constitui um bloco homogêneo, longe disso. A causa verdadeiramente justa pode variar diametralmente quando observada de um ponto de vista ou de outro. Uns

\footnotetext{
${ }^{2}$ Assim que tomei a decisão de fazê-lo, já no terço final das atividades do semestre, os alunos e alunas que frequentavam as duas turmas foram perguntados a respeito da possibilidade de a experiência ser relatada em artigo científico. Todos e todas concordaram de bom grado e responderam a um questionário, que será retomado na parte final do artigo. A todos os alunos e alunas, portanto, sou grato pela gentileza e confiança.
}

\begin{tabular}{l|l|l|l|l|l|l} 
(C) ETD -Educ. Temat. Digit. & Campinas, SP & v.17 & n.3 & p.673 & set./dez.2015 & ISSN $1676-2592$
\end{tabular}


advogaram pela verdade dos deuses, outros pela verdade dos doutos. Outros ainda pela quintessência do materialismo dialético; tantos outros, pela sua negação.

$\mathrm{Na}$ qualidade de fenômeno característico do mundo moderno secularizado e desencantado, como o qualificou Max Weber, a atuação do intelectual se esgarça daquela do sábio ensimesmado para emergir como figura que faz as vezes de conselheiro do príncipe. ${ }^{3}$ Alexis de Tocqueville, em seu L'Ancien Régime et la Révolution (1967), mostra como, no século XVIII, os escritores tornaram-se a camada mais influente na França, inclusive na esfera política. Com efeito, quando se alude à atividade do intelectual - para além da distinção puramente instrumental entre aqueles que executam tarefas manuais para sobreviver e os que, por outro lado, não as executam prioritariamente (escritores, jornalistas, professores, profissionais liberais etc.), o que está em jogo, de uma perspectiva sociológica, é antes a função da natureza de tal processo. Nesses termos, um escritor (cuja atividade é tomada indistintamente como intelectual) que não participe das questões mais amplas que dizem respeito à sua atividade à sociedade em que vive, não passa de um operador (no sentido estrito, como aquele que executa uma ação) de seu ofício, ao passo que um trabalhador manual de fábrica, ao aderir ao sindicato de sua categoria e participar ativamente da luta política que deriva dessa participação, torna-se um intelectual em seu sentido pleno. O intelectual, com efeito, seria "alguém que não faz as coisas, mas reflete sobre coisas, que não maneja objetos, mas símbolos, alguém cujos instrumentos de trabalho não são as máquinas, mas as ideias" (BOBBIO, 1996, p. 68).

A atividade intelectual, por essa perspectiva, tem como característica distintiva a capacidade elaborativo-abstrata como uma dimensão descolada e amplificada ou, segundo o entendimento corrente, autônoma. O que se questiona, exatamente, é o status dessa pretensa autonomia e de sua orientação, vale dizer, se ela se refere prioritariamente à esfera do pensamento (ficando a ela restrita) ou se é orientada para justificar (ou negar) o estado de coisas estabelecidas. Dito em outras palavras, estaria o intelectual moderno aprisionado à condição de homem-contradição, de acordo com a hipótese sartriana segundo a qual ele se vê indelevelmente cindido entre as exigências da universalidade presentes na prática científica e os particularismos sociais, culturais e econômicos que condicionam sua vida concreta? Seria ele um universalista na técnica, mas particularista em suas ações, subsumidas à ideologia dominante? Criadores, mediadores ou meros reflexos do mundo ao qual reportam?

\footnotetext{
3 Desde a República de Platão interroga-se sobre o papel daqueles que têm como missão organizar intelectualmente a ordem social - vale dizer, coloca-se em pauta a relação entre teoria e praxis, pensamento e ação, vida contemplativa e vida ativa. Karl Marx reelaborou esse que é um dos principais dilemas da filosofia politizando-o, em sua undécima tese sobre Feuerbach: "os filósofos só interpretaram o mundo de diferentes maneiras; do que se trata é de transformá-lo" (MARX e ENGELS, 1998, p. 103). Convite à ação e, por conseguinte, repúdio ao pensamento idealista do qual tentava se desvencilhar, a elaboração de Marx contém em si uma atitude anti-intelectualista que, como bem nos lembra Norberto Bobbio, questiona em seu cerne a posição segundo a qual os intelectuais são o sal da terra: no princípio era o ato, e não a palavra. (BOBBIO, p. 1996, p. 111).
} 


\section{POSIÇÕES INTELECTUAIS POSSÍVEIS}

Como já observado, a ementa ${ }^{4}$ da disciplina EL 142 é bastante abrangente, o que me deixou à vontade para trabalhar a temática dos intelectuais dando ênfase ao campo educacional e à relação do tema com a universidade A proposta apresentada, em linhas gerais, dividia-se em dois momentos: no primeiro seriam discutidos, com o auxílio de bibliografia pertinente, os fundamentos históricos, intelectuais e sociais envolvidos na constituição da universidade moderna (Europa) e a influência desse modelo na consolidação da universidade no Brasil; na segunda parte do curso, a ideia foi a de articular tal discussão com a temática dos intelectuais na sociedade de uma forma mais abrangente.

A bibliografia das duas primeiras partes da disciplina eu já havia trabalhado em outro curso, que tratava da formação histórica da universidade. ${ }^{5}$ Foram discutidas, em sequência, as seguintes obras que, em conjunto, ofereceram uma gama diversificada de reflexões: $O s$ intelectuais na Idade Média, de Jacques Le Goff (2003); O declínio dos mandarins alemães, de Fritz Ringer (2000), As três culturas, de Wolf Lepenies (1996); Sobrados e Mucambos, de Gilberto Freyre (1985), além da coletânea organizada por Jonh E. Steiner e Gerard Malnic, Ensino Superior: conceito e dinâmica (2006).

$\mathrm{Na}$ segunda parte do semestre, a questão referente aos intelectuais e seu papel na sociedade e na universidade foi o foco, a partir da perspectiva de alguns autores e respectivos pontos de vista. Duas visões, ou duas atitudes intelectuais, contudo, balizaram as discussões à guisa de fios condutores ideais-típicos ${ }^{6}$ : a primeira exposta na obra A Traição dos Intelectuais (2007), de Julien Benda, publicada em 1927, na qual o filósofo francês defende uma postura intelectual radicalmente racionalista e desinteressada e qualifica como traidores todos aqueles que, na condição de intelectuais, orientam sua ação para além dos limites abstratos da justiça, da verdade e da razão. ${ }^{7}$ Benda, adversário intransigente das paixões políticas e das ideologias que as alimentam, o longevo crítico da filosofia instintiva bergsoniana logrou à posteridade um dos mais belos e apaixonantes libelos em favor de uma postura intelectual anacrônica e incompatível com o século que desabrochava, cindido por guerras ideológicas e que veria emergir a segunda atitude intelectual ideal-típica que elegemos para fins analíticos no curso (e que seria sua antípoda): o engajamento.

O intelectual que mais bem representou essa posição engajada, que obteve repercussão ubíqua e que foi alçado à condição de figura pública, a ponto de esse engajamento se tornar

\footnotetext{
${ }^{4}$ Onde se lê: "Problematização de questões de interesse para a Educação no cenário nacional contemporâneo, em uma perspectiva interdisciplinar e articulada".

${ }^{5} \mathrm{Na}$ disciplina EP 566 - Seminário de Integralização Curricular I, ministrada no segundo semestre de 2014. Aproveito para agradecer ao colega Alexandro Paixão, que me apresentou uma parte desta bibliografia e organizou este curso.

${ }^{6}$ No sentido metodológico que Weber dá ao termo, vale dizer, como estratégia analítica, que não se refere, na sua totalidade, a um modelo real, mas serve ao pesquisador como síntese, no sentido de reunir o máximo possível das características que se busca (WEBER, 2001).

7 Além do próprio livro de Benda, o artigo de Carlota Boto Traição dos intelectuais. Um tema nosso contemporâneo (2008-2009), serviu de parâmetro para a discussão sobre o tema.
}

\begin{tabular}{l|l|l|l|l|l|l} 
(C) ETD -Educ. Temat. Digit. & Campinas, SP & v.17 & n.3 & p.673 & set./dez.2015 & ISSN $1676-2592$
\end{tabular}


quase sinônimo de sua própria figura, foi indubitavelmente o filósofo francês Jean-Paul Sartre. O engajamento sartriano testemunha não apenas as posições políticas assumidas pelo pensador no período após a Segunda Guerra, mas (principalmente) confere coerência, no plano pessoal, à filosofia original que Sartre erigiu: o existencialismo. Elegemos as três conferências proferidas por Sartre no Japão, em 1965, publicadas sob o título de Em Defesa dos Intelectuais (1994) como o texto a partir do qual discutiríamos sua postura engajada. Na condição de figura pública mais influente de sua época, uma espécie de fenômeno midiático avant la lettre, Sartre fez de seus engajamentos o exemplo mais delineado do intelectual como aquele que participa ativamente das tormentas de seu tempo, e que toma partido a favor dos ideais que considera justos.

A partir dessas duas posições de ideias antitéticas de atitude intelectual possível, o distanciamento e o engajamento, foi também trabalhada com os estudantes outra hipótese que qualifiquei como intermediária, na qual a postura intelectual típica oscila entre engajar-se e distanciar-se. Para trabalhar e problematizar esse tipo de posicionamento, propus a leitura da obra Representações do Intelectual (2005), de Edward Said, intelectual palestino. Fruto de um conjunto de conferências proferidas e transmitidas pela BBC de Londres em 1993, ${ }^{8}$ o livro, publicado no ano seguinte, traz uma virtuosa cepa de reflexões que permitem vislumbrar o espectro de possibilidades que há entre um polo e outro. Said as explora, muitas vezes em tom normativo, de forma perspicaz e aprofundada.

Outros dois textos seminais examinados nesse momento do curso foram as conferências Ciência como vocação e Política como vocação ${ }^{9}$, proferidas por Max Weber em 1918 para estudantes universitários em Munique. Além do debate mais amplo no qual se inserem as mencionadas conferências, que dizia respeito tanto aos desafios e impasses nos quais a sociedade alemã se via inserida (em particular a guerra) quanto às questões filosóficas e epistemológicas que derivavam da tradição mandarim, ${ }^{10}$ Weber coloca questionamentos essenciais sobre o próprio sentido do saber e da "profissão de fé" do sábio nas sociedades modernas. Ao problematizar e relativizar os impactos do processo paulatino de especialização presente na prática científica moderna, sobretudo nas universidades, no qual o método e não a inspiração (ou a paixão, como preferia) é a marca distintiva, Weber indica que a ciência não pode ser atividade exclusiva dos reis-filósofos, e tampouco perfaz uma prática asséptica, isenta de valores.

As reflexões de Weber foram particularmente importantes por que trouxeram à baila questionamentos sobre a prática docente e a recorrente confusão, por parte dos estudantes, em elevar a figura do bom professor (pelos recursos que hoje chamaríamos de pedagógicos) ao patamar de mentor intelectual. Weber matiza, primeiramente, a ideia segundo a qual o sucesso em sala de aula representa "a" medida da boa prática científica e, depois, questiona a também

\footnotetext{
${ }^{8}$ Trata-se das prestigiosas Conferências Reith (The Reith Lectures), inauguradas em 1948 por Bertrand Russell.

${ }^{9}$ Publicadas sob o título de Ciência e Política: duas vocações (1972).

${ }^{10} \mathrm{Em}$ especial os rumos do ensino universitário na Alemanha: se alinhado à tradição idealista (cultivo do Geist, formação para a Kultur), ou se voltado às tendências modernas de especialização dos saberes práticos (Building).
} 
equivocada tendência dos estudantes em equivaler a posição do docente à do intelectual: tratase de vocações por vezes coincidentes, porém de natureza distintas.

Um conjunto de perspectivas foi ainda apresentado para debater as três posições intelectuais anteriormente aludidas. ${ }^{11}$ Trabalhamos os seguintes ensaios, presentes na coletânea O Silêncio dos Intelectuais (2006), organizada por Adauto Novaes: Intelectual engajado: uma figura em extinção?, de Marilena Chauí; A crise dos universais, de Sérgio Paulo Rouanet; $O$ cientista e o intelectual, de Renato Janine Ribeiro; O imperativo ético de Sartre, de Franklin Leopoldo e Silva e J. P.-Sartre, um intelectual engajado, de J-F. Sirinelli. Além desses ensaios, a obra referencial de Norberto Bobbio Os intelectuais e o poder (1996), e a coletânea organizada por Alberto Aggio, Gramsci. A vitalidade de um pensamento (1998), formaram a espinha dorsal que sustentou os debates e as discussões.

Finalmente, dois textos foram sugeridos como leitura obrigatória com vistas a problematizar as atuais condições do trabalho intelectual na universidade, em particular no Ensino Superior brasileiro: A universidade em ritmo de barbárie (1986), de José Arthur Gianotti, e A educação da miséria: particularidade capitalista e educação superior no Brasil (2014), de Lalo Watanabe Minto. Marcado pelo acelerado processo de especialização e de quantificação dos resultados (sob a égide do famigerado produtivismo acadêmico), o modelo universitário que se desenvolveu no país, elitista desde seu cerne, é pouco afeito à atividade intelectual em seu sentido mais amplo, já que impõe aos seus quadros uma lógica (sobretudo no âmbito das ciências humanas e sociais) que conduz à massificação e ao empobrecimento. Como um dos efeitos mais perversos desses processos está o fato de que, aos olhos das novas gerações de estudantes (muitas vezes com toda justiça) o professor universitário não passa de mero reprodutor de saberes técnicos, que busca a todo custo progredir na carreira e publicar, isso à custa da salutar função docente/educativa que deveria balizar sua ação, mas que é formalmente negligenciada. ${ }^{12}$

\section{PANORAMA GERAL DAS TURMAS E METODOLOGIA}

Os encontros com os alunos e alunas matriculados na disciplina EL 142 aconteceram nas tardes de terça-feira (turma A) e nas noites de sexta-feira (turma B), de março a julho de 2015. No total, havia 42 matriculados na turma vespertina e 25 matriculados na turma noturna,

\footnotetext{
${ }^{11}$ No caso específico do engajamento sartriano, foram apresentadas críticas à própria natureza dessa atitude engajada, uma vez que se tratava de um ponto de muita relevância que eu julgava importante trabalhar com os alunos e alunas matriculados nas duas turmas. A discussão dizia respeito à problematização a respeito de toda uma geração de intelectuais que, como Sartre, defenderam uma causa (o comunismo soviético) em nome de um ideal humanista que, na prática dos seus métodos, promovia o terror. Longe de colocar em causa a atitude de Sartre pelo viés moral ou político-ideológico, a ideia era a de apresentar elementos para questionar os motivos da permanência (e não da adesão) a essa atitude, isto é, a postura intelectual imune (ou pouco aberta) a revisões e autoquestionamentos.

${ }^{12}$ Como se poderá observar pelo relato dos estudantes que apresentaremos a seguir.
}

\begin{tabular}{l|l|l|l|l|l|l} 
(C) ETD -Educ. Temat. Digit. & Campinas, SP & v.17 & n.3 & p.673 & set./dez.2015 & ISSN $1676-2592$
\end{tabular}


configurando um total de 67 alunos e alunas (gráfico 10). ${ }^{13} \mathrm{O}$ primeiro dado a ser destacado se refere ao perfil de gênero: nas duas turmas, a maioria dos discentes era do sexo feminino - 9 homens para 33 mulheres (turma A) e 7 homens para 18 mulheres (turma B), o que pode ser explicado em partes pelo próprio perfil das carreiras escolhidas pelos discentes matriculados, já que não havia estudantes das áreas de ciências exatas e engenharias (cujo perfil é predominantemente masculino).

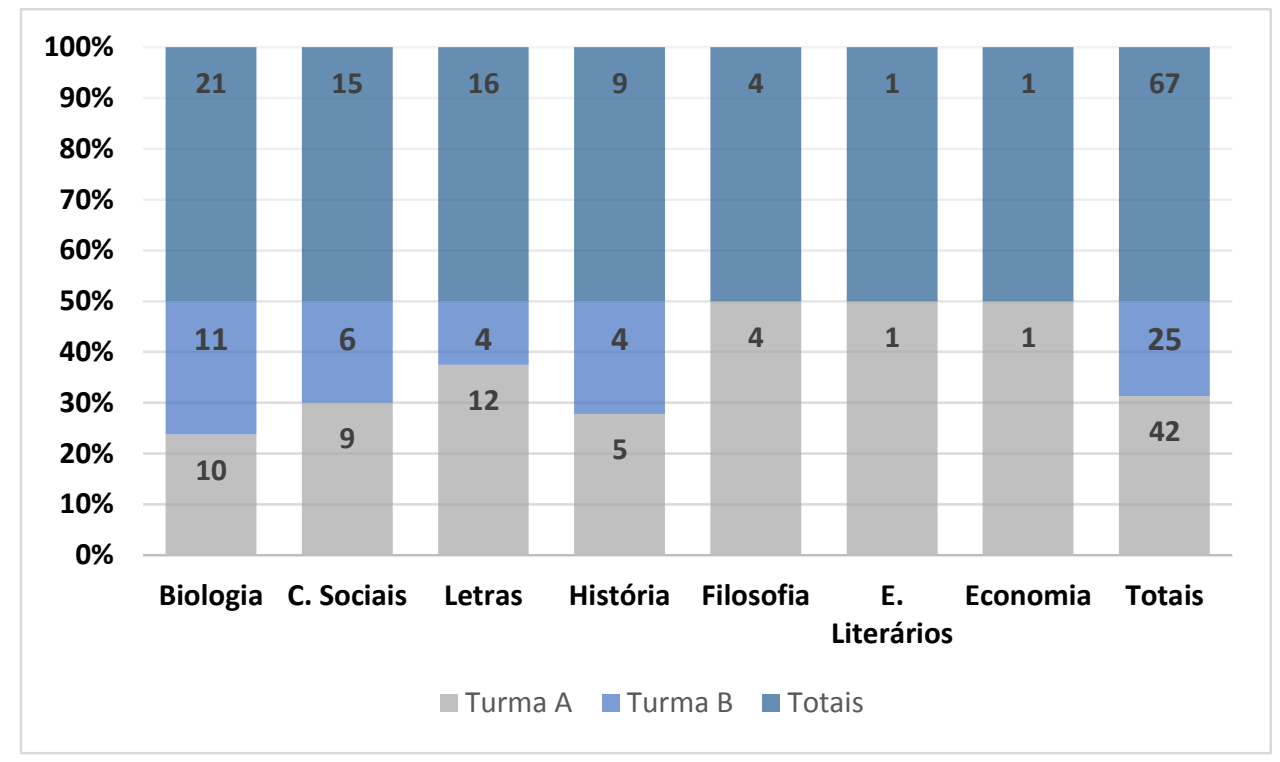

GRÁFICO 1: Matriculados, segundo as carreiras - Turmas A e B

Fonte: Dados da Diretoria Acadêmica da Unicamp - DAC/Unicamp.

Desse total, 47 frequentavam cursos na modalidade licenciatura e 20, na modalidade bacharelado. A média de idade girou em torno dos 22 anos para a turma vespertina e 23 anos para a turma noturna, não acompanhando, assim, a tendência de discrepância que costuma caracterizar o perfil etário das turmas noturnas em relação às turmas diurnas. ${ }^{14}$ Os demais dados referentes ao perfil dos alunos e alunas matriculados, que diziam respeito também aos motivos

\footnotetext{
${ }^{13}$ Faz-se importante ressaltar que, do total de matriculados, uma pequena parte frequentou esporadicamente o curso, e não participou das avaliações. Dos 42 matriculados no início do semestre na turma A, 40 mantiveram o vínculo com a disciplina, sendo que apenas 1 não entregou a avaliação final; na turma $\mathrm{B}$, todos mantiveram suas matrículas ativas até o final do semestre letivo, ainda que 5 dos 25 matriculados (20\%) não tenham participado da avaliação final.

${ }^{14}$ A média etária dos estudantes que optam por cursos noturnos costuma ser mais elevada em relação à média daqueles matriculados no período diurno ou integral. Contudo, neste caso, apenas um quarto dos discentes matriculados na turma B optou por cursos noturnos quando da inscrição no vestibular da universidade. Cabe lembrar que os estudantes da Unicamp gozam de liberdade para cursar parte do currículo obrigatório e eletivo de suas carreiras em períodos à sua escolha.
} 
da opção por frequentar essa disciplina em específico (entre outros assuntos) foram obtidos por meio de um questionário, de preenchimento não obrigatório. ${ }^{15}$

As 12 questões ali contidas objetivavam, em resumo, compreender os seguintes aspectos: a) principais motivações para escolher cursar a disciplina (necessidade de cursar uma EL, aproximar-se de temáticas diferentes, horário compatível com as necessidades, ementa da disciplina ou outro motivo); b) opinião a respeito da importância da reflexão sobre o papel dos intelectuais na sociedade e, em específico, do estudo do tema em um curso regular de graduação; c) indicação dos autores mais importantes trabalhados na disciplina e os motivos da escolha; d) indicação da atitude ideal-típica mais adequada para o intelectual: distanciamento ou engajamento; e) reflexão sobre a atitude do professor da disciplina: se deixou transparecer ou optou deliberadamente por uma dessas duas posições durante o semestre (e, por conseguinte, se concordaram ou não com ela); e, por fim, f) opinião a respeito da ideia de os intelectuais constituírem uma "camada à parte" na sociedade.

Outra estratégia utilizada na tentativa de captar a percepção dos alunos e alunas deu-se por intermédio uma proposta mais aprofundada de reflexão, incluída na avaliação escrita que, em conjunto com os seminários ${ }^{16}$ baseados no já citado livro Representações do intelectual, de Edward Said, compuseram as médias semestrais finais. Na terceira questão lia-se a seguinte pergunta: "A Unicamp e o curso de graduação que você escolheu configuram espaços privilegiados para a atividade intelectual em seu sentido mais amplo"? Os apontamentos que se seguem, portanto, baseiam-se nos meus registros em sala a partir das percepções que extraía dos debates, da bibliografia geral proposta para a disciplina, bem como das duas estratégias empíricas há pouco citadas. Tudo isso permeado (e temperado) pelos agudos apontamentos que Said nos colocava, a cada encontro, nos seminários que fecharam o semestre de atividades.

\section{ANÁLISE E PERSPECTIVAS}

Como dado inicial, faz-se importante destacar que os motivos alegados pelos discentes para se matricularem na disciplina não levaram em conta o tema específico (intelectuais e universidade) que seria nela trabalhado. Por causa de questões técnicas, ao pesquisarem sobre a disciplina no período de matrícula, as únicas informações disponíveis eram a já citada ementa, que é bastante vaga, o nome do professor responsável e os respectivos horários de oferecimento. ${ }^{17} \mathrm{O}$ detalhamento do programa, bem como a bibliografia e o andamento das

\footnotetext{
${ }^{15}$ Em razão disso, nem todos os discentes responderam ao questionário, cuja aplicação deu-se nas duas últimas semanas letivas. No total, 25 dos 40 alunos e alunas da turma A que, efetivamente, frequentaram a disciplina, responderam o questionário (62,5\%); já na turma B, a participação foi um pouco maior: 14 dos 20 alunos (70\%). ${ }^{16}$ Os alunos e alunas dividiram-se em grupos, cada qual responsável por discutir com o professor e com os colegas dois capítulos do livro, a saber: "Representações do intelectual"; "Manter nações e tradições à distância"; "Exílio intelectual: expatriados e marginais"; "Profissionais e amadores"; "Falar a verdade ao poder" e "Deuses que sempre falham".

17 Em algumas unidades d Unicamp, os programas completos das disciplinas são disponibilizados em seus respectivos sites com alguma antecedência em relação ao período de matrículas, medida que auxilia os estudantes a orientarem suas escolhas. No caso específico da Faculdade de Educação, embora os programas completos estejam disponíveis com antecedência, isso não ocorre no site da Faculdade. O estudante interessado pode
} \begin{tabular}{l|l|l|l|l|l|l}
\hline (C) ETD -Educ. Temat. Digit. & Campinas, SP & v.17 & n.3 & p.673 & set./dez.2015 & ISSN 1676-2592
\end{tabular} 
atividades, os estudantes só conheceriam no nosso primeiro encontro. A falta dessa informação não me permitiu inferir a medida do interesse prévio dos estudantes pela temática como primeiro parâmetro considerado na matrícula.

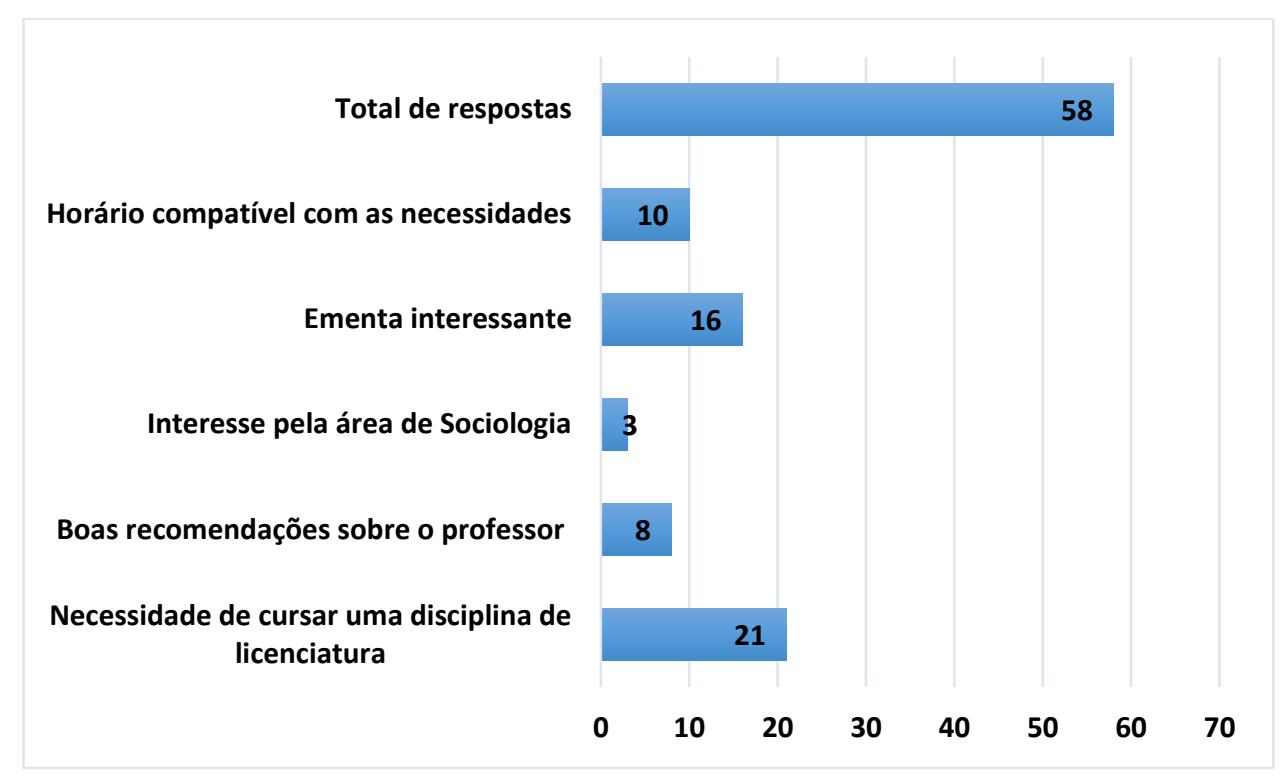

GRÁFICO 2: Motivo(s) do interesse em cursar a disciplina - Turmas A e B ${ }^{18}$ Fonte: Dados do autor

Como era de se esperar, foram preponderantes motivos pragmáticos como a necessidade de cursar uma EL ou horário compatível com as demais atividades, assim como a ementa genérica e abrangente. Para refinar a percepção em relação ao interesse (aqui entendido como relevância) pelo tema dos intelectuais, propus que indicassem (deixando aberto para comentarem a resposta) a necessidade ou a superfluidade dessa reflexão no âmbito dos cursos de graduação nas universidades públicas. Apenas uma aluna apontou o fato de a discussão não ser necessária, ainda que com a ressalva de que o assunto "contribuiu para eu começar a refletir sobre certas coisas relacionadas" (Ciências Biológicas/Enfermagem). ${ }^{19}$ Todos os demais respondentes apontaram sua importância, variando apenas a argumentação. ${ }^{20}$

consultá-los apenas na Secretaria de Graduação da Faculdade. Na prática, a internet é o meio quase exclusivo para obtenção destas informações, sobretudo por parte dos discentes das outras unidades da Unicamp que frequentam disciplinas de licenciatura ofertadas pela Faculdade de Educação.

${ }^{18}$ A resposta era aberta, por isso, considerei todas as indicações possíveis relatadas. Como exemplo, boa parte dos alunos e alunas que enfatizaram a necessidade/obrigação de cursar uma disciplina de licenciatura também indicaram como fator simultâneo a compatibilidade de horários.

${ }^{19}$ Doravante, sempre que citarmos a resposta de um aluno ou aluna, indicaremos, entre parênteses, o curso no qual está matriculado ou matriculada, bem como, se for o caso, se já possui outra formação em curso superior, como na citação a que se refere esta nota. Não foi cobrada a identificação pessoal nos questionários, para evitar constrangimentos ou respostas enviesadas.

${ }^{20}$ São exemplos: "Acho necessário para despertar nos alunos o senso de responsabilidade que eles têm para com a sociedade" (Ciências Sociais); "Como a Unicamp apresenta um caráter de instituição de pesquisa, acho \begin{tabular}{|c|c|c|c|c|c|c|}
\hline (C) ETD -Educ. Temat. Digit. & Campinas, SP & v.17 & n.3 & p.673 & set./dez.2015 & ISSN 1676-2592
\end{tabular} 
O dado alarmante, contudo, é que a reflexão sobre o papel dos intelectuais na sociedade e sua relação com a universidade foi apontada por $70 \%$ dos discentes como totalmente ausente nos cursos que frequentam. A tomar nossa amostra qualitativa como parâmetro, o panorama é ainda mais grave fora do âmbito das ciências humanas, ao passo que todos os nove alunos ou alunas que indicaram já ter trabalhado a temática em sala de aula (direta ou indiretamente) frequentam cursos dessa área do conhecimento. ${ }^{21}$ Temática considerada importante pela maioria dos estudantes é, contudo, negligenciada. ${ }^{22}$

Outro aspecto relevante abordado dizia respeito à posição que expressaria com mais fidelidade a visão de cada discente sobre os intelectuais, proposta nos seguintes termos: a) "Sim, somos todos intelectuais", ou b) "Não, os intelectuais constituem uma camada à parte na sociedade". ${ }^{23}$ Dezoito estudantes preferiram a alternativa "b", e outros 10, a alternativa "a". Já de início, o fato de apenas 28 estudantes terem respondido à questão denota a flagrante dificuldade de percepção sobre o tema, mesmo após meses de discussão e recolocação do problema sob diversos ângulos. ${ }^{24}$

completamente necessário discutir qual seria o papel do intelectual/pesquisador/profissional, principalmente na área de humanidades" (História); "É absolutamente necessário!" (Estudos Literários); "Muito necessário! Foi a minha EL mais importante e produtiva" (História); "Profundamente necessário [...]" (História); "Necessário, principalmente a questão do engajamento do intelectual, tão importante para a discussão em tempos em que basta um clique para emitir uma opinião e tomar uma posição" (Letras); "Necessário, para todos os cursos!" (Ciências Sociais); "Considero muito necessário, principalmente por que nos coloca a reflexão sobre nossa posição enquanto estudantes" (Filosofia).

${ }^{21}$ Quatro eram estudantes de História, três de Ciências Sociais e dois de Letras.

${ }^{22}$ Algumas respostas merecem ser destacadas: "Essa temática não é presente no meu curso. Nunca tinha pensado nisso" (Letras); "Não é presente no meu currículo, nunca havia pensado sobre" (Ciências Biológicas); "Essa disciplina foi a primeira a tratar dessa temática" (Biologia); "Não, com certeza não é comum" (História); "Foi a primeira vez que me deparei com essa questão" (Letras); "Não acho nada comum" (Letras); "Nunca havia pensado a respeito e tal reflexão acrescentou muito na minha perspectiva sobre o assunto" (Letras).

${ }^{23}$ Essa falsa dicotomia foi trabalhada de diferentes formas pela perspectiva dos autores já citados (Benda, Sartre, Gramsci, Bobbio etc.). A distinção mais importante que quis analisar foi aquela que grosso modo diz respeito à perspectiva segundo a qual a atividade intelectual deriva da ação de todo e qualquer ser pensante, vale dizer, que usa o seu intelecto para um fim (alternativa "a"); por outro lado, em contraposição, só poderia ser considerado como intelectual aquele indivíduo que orienta suas ações para além de seu âmbito original de atuação e reflete sobre o mundo onde vive (alternativa "b"). Também nesta questão incitei-os a comentarem suas opções, com o fito de perceber as nuances nas respostas, oriundas de outras posições possíveis e até mesmo esperadas. Em uma dessas acepções esperadas (que apareceu com certa frequência nas discussões), a alternativa "a" poderia ser subdividida: todos somos intelectuais, à exceção daqueles que só cumprem tarefas manuais.

${ }^{24}$ São exemplos de resposta: alternativa "a": "Acho que a intelectualidade está relacionada ao pensamento, e todos possuem a capacidade de pensar" (Ciências Sociais); "Porque o exercício de reflexão pode ser livremente incentivado para melhorar o conhecimento crítico" (História); "Gosto desta descrição de Gramsci, apesar de ressalvas"; alternativa "b": "Todos podem ser intelectuais, mas não são todos que o são, é preciso, no mínimo, uma reflexão sobre sua sociedade" (História); "Geralmente intelectuais são pessoas com características específicas, como inclinação à reflexão e aos estudos, e nem todos se encaixam nesse conceito" (Letras); "Acredito na necessidade de formação intelectual e que nem todos têm acesso a ela" (Filosofia); "É impossível dizer que todos somos intelectuais, já que muitos vão exercer atitudes que não buscam contra dispor o sistema" (Ciências Sociais); "Embora nem todos possuam alguma finalidade nem estejam isolados, pequena é a parcela da sociedade que se dedica a pensar de fato sobre as mazelas da vida" (Ciências Biológicas); "Porque considero que os verdadeiros intelectuais estão engajados e têm participação ativa na sociedade" (Ciências Sociais); "Porque o intelectual surge mediante à prática reflexiva e sua característica principal é a de crítica às autoridades e as 'representações' sobre a realidade" (Ciência Sociais). 
O posicionamento mais adequado ao intelectual também configurou problematização perene durante o semestre, como já observado. De um lado a atitude distanciada, isenta de valores que expressem qualquer posição (ou paixão) mundana, na qual o intelectual aparece como alguém que não se compromete e se vê como a consciência da humanidade. O epítome desse tipo nos oferece Julien Benda, para o qual, segundo bem observa Said, os intelectuais "são personagens simbólicos, marcados por sua distância obstinada dos problemas práticos" (SAID, 2005, p. 22). Na posição oposta está o intelectual que necessariamente se engaja nas lutas que considera justas, concentrando nelas todos os recursos de que dispõe. É aquele que sai de sua esfera de competência e torna público seus posicionamentos; é "o escritor de atualidades que opina e intervém em todos os acontecimentos relevantes, à medida que vão se sucedendo uns aos outros. É um estado de vigília permanente" (CHAUÍ, 2006, p. 25). Trata-se do "especialista do saber prático", segundo os termos sartrianos.

Novamente o que se pretendeu, para além de ser informado sobre o nível de reflexão a respeito das opções apresentadas a cada aluno e aluna durante o curso, foi a tentativa de compreensão aprofundada de como cada um e cada uma entendia a vocação do intelectual na sociedade e, em particular, na universidade. Em outros termos: seria o intelectual, como portador de uma mensagem (ou de uma verdade), anacrônico? Haveria público interessado em ouvir esses indivíduos? Em caso positivo, essas pessoas coadunariam a sua ação política, religiosa, moral, ideológica etc. à atuação deles? O intelectual ligado à universidade pode (ou deve) deixar transparecer suas paixões quando no exercício de suas funções profissionais? Dever-se-ia exigir do intelectual, como condição necessária ao ofício, a imparcialidade e o distanciamento?

Edward Said problematizou essas questões por diversos ângulos em linguagem penetrante, direta e concisa - muito em razão da natureza do texto dele, que foi discutido, como observado -, fruto de conferências radiofônicas com limite de tempo estabelecido. ${ }^{25}$ Vale lembrar que o convite feito a Said para as conferências gerou enorme repercussão e polêmica no meio intelectual, em especial o inglês. Jornalistas e intelectuais questionavam o fato de um pensador engajado na luta palestina, cujos livros eram considerados por muitos como vilipêndios à cultura ocidental, pronunciar as Lectures inauguradas por Bertrand Russell. Em

\footnotetext{
É bem verdade que questões abrangentes como esta (e que, ainda, exigia a escolha por "a" ou "b") tendem a não ser respondidas, seja por dificuldade de raciocínio analítico, seja por não contemplar (já no comando da assertiva) possíveis alternativas à resposta. Contudo, como estratégia proposital de apreensão da visão geral de cada aluno e aluna a respeito de uma das questões centrais tratadas no decorrer da disciplina, a iniciativa se mostrou, a meu ver, bem-sucedida. Ressalte-se ainda, nesse sentido, que mesmo os respondentes que tentaram vislumbrar um caminho do meio, acabaram por assumir uma posição ou outra, como nestes exemplos: 'Concordo com a 'b', apesar que essa não é uma configuração ideal" (História); "Só se em 'a' estiver pressuposto que todos têm a capacidade de ser - ou seja, de refletir, questionar e tornar a própria realidade inteligível de forma aprofundada [...]" (Ciências Sociais); "Escolho 'b', com a ressalva que camada à parte não significa ser melhor" (Estudos Literários); ou ainda, "Nenhuma das duas. Forçando um pouco o que eu penso ser um intelectual, eu escolheria 'b', mas com a ressalva de que só escolho ela por não acreditar que sejamos todos intelectuais” (Letras). Apenas uma aluna foi categórica em sua resposta: "Não cheguei a uma conclusão clara sobre o assunto" (Letras).

25 Trinta minutos cada uma. Os áudios de todas as Conferências Reith, desde 1948, podem ser acessados em: http://www.bbc.co.uk/radio4/features/the-reith-lectures/archive/.
}

\begin{tabular}{l|l|l|l|l|l|l} 
(C) ETD - Educ. Temat. Digit. & Campinas, SP & v.17 & n.3 & p.673 & set./dez.2015 & ISSN 1676-2592
\end{tabular}


outras palavras, Said não reuniria condições morais para tratar de um assunto universal: o papel dos intelectuais.

De fato, Said afirma a acepção segundo a qual o intelectual não consegue se desligar por completo dos laços que os une a alguma cultura, língua ou causa. Também sinaliza que, embora a ação do intelectual deva ser sempre aquela de questionamento ao poder e os poderosos, isto não configura privilégio dos pensadores rotulados como de esquerda (Benda seria o exemplo categórico de homem que se poderia considerar de direita e que combateu, à sua maneira, o nacionalismo empedernido dos homens de sua época). Sobretudo, Said faz o elogio do intelectual outsider, ${ }^{26}$ crítico constante que deve se ver livre das amarras; um marginal que tem como missão falar a verdade ao poder, e não o aconselhar. Universal em suas pretensões e princípios, aproxima-se de Benda; imerso na contradição dessa pretensão universal que persegue e os particularismos que permeiam as relações sociais concretas, flerta com a posição sartriana.

Esse já aludido caminho do meio, no qual o intelectual se engaja, mas mantém espírito permanente de autocrítica, e orienta sua ação tendo como norte e parâmetro a justiça da causa e não um a priori ideológico, seduziu boa parte dos alunos e alunas: "nunca a solidariedade antes da crítica" (SAID, 2005, 43). Isso se refletiu inequivocamente nas respostas às questões propostas tanto no questionário quanto na avaliação. Quando pedi para que apontassem o autor cuja posição intelectual seria a mais frutífera e interessante, ofereci cinco opções - e respectivas posições ideal-típicas: distanciada (Benda), engajada (Sartre e Gramsci) ou intermediária (Weber e Said), conforme os dados abaixo (Gráfico 3).

\footnotetext{
${ }^{26}$ Este ponto foi profundamente trabalhado nas discussões em sala. Said afirma peremptoriamente que perseguiu a posição ontológica de exilado, isto é, de intelectual deslocado e perenemente inconformado. Da mesma maneira, criticou com veemência os intelectuais que atrelam sua atuação a instituições ou poderes estabelecidos. Acontece que Said, embora (ao que parece) nunca tenha feito uso de sua posição como figura pública estabelecida para fazer circular suas ideias, era figura de proa do mainstream acadêmico de sua época, o que o colocava na curiosa condição de "exilado" na Universidade de Colúmbia, em Nova Iorque. Obviamente, Said utilizava o termo outsider como metáfora, mas seu posicionamento nos convida a um raciocínio suplementar: poderia um intelectual de fato outsider (sem status, sem circulação, que leciona em uma universidade periférica etc.) se dar ao "luxo ontológico" de agir como o fez Said?
}

\begin{tabular}{c|c|c|c|c|c|c}
\hline (C) ETD-Educ. Temat. Digit. & Campinas, SP & v.17 & n.3 & p.673 & set./dez.2015 & ISSN 1676-2592 \\
\hline
\end{tabular}




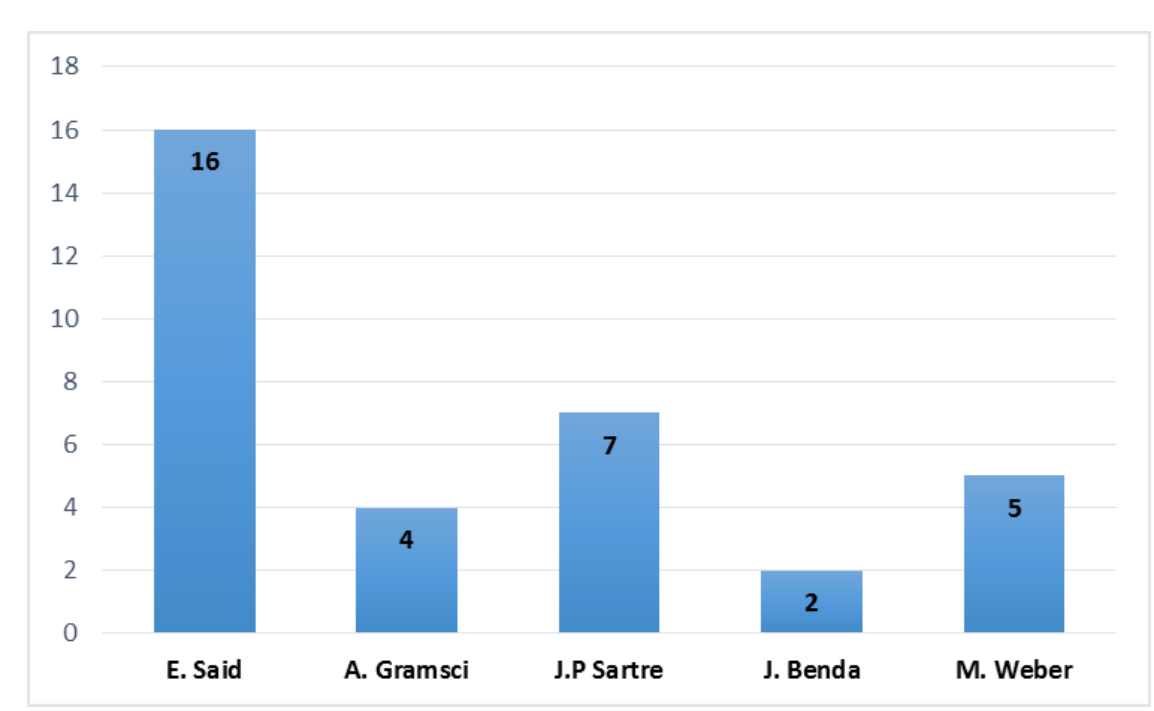

GRÁFICO 3: Autores trabalhados no curso, segundo o interesse discente Fonte: Dados do autor.

Como hipótese, as justificativas pela escolha de Said derivam, em parte, por se tratar do autor cujas ideias trabalhamos por mais tempo, em quatro aulas durante os seminários, mas, sobretudo, a meu juízo, pela contemporaneidade de suas reflexões. ${ }^{27}$ Isso nos conduz às duas últimas questões trabalhadas e que gostaria de relatar. A primeira diz respeito à discussão que balizou o tema maior dos intelectuais: a universidade, em particular, o Ensino Superior Público, como espaço (ou não espaço) da atividade intelectual em seu sentido amplo. A segunda, referese à minha própria atuação como intelectual e docente. No primeiro caso, como já aludido, inclui na avaliação a seguinte proposta de reflexão: A Unicamp e o curso de graduação que você escolheu configuram espaços privilegiados para a atividade intelectual em seu sentido mais amplo? Para trabalhar a segunda percepção, pedi, primeiramente, para que respondessem de forma aberta no questionário a respeito da maneira pela qual interpretaram meus posicionamentos no decorrer do semestre; vale dizer, se o professor da disciplina, também ele um intelectual, teria agido de maneira engajada, ${ }^{28}$ distanciada ou ambas ao tratar dos diversos assuntos, não só os que diziam respeito ao tema da disciplina, mas também aos demais que apareceram nas discussões, como política, cultura, eleições, representação estudantil etc. e, por fim, solicitei para que indicassem o posicionamento que julgavam o mais adequado para um professor de universidade pública.

\footnotetext{
${ }^{27}$ São exemplos: "Said parece bastante coerente com suas ideias e muito imparcial nas condutas" (Ciências Biológicas); "Said, tanto pela história de vida pessoal quanto intelectual" (Letras); "Said me pareceu mais interessante por criticar o profissionalismo e elogiar o amadorismo, ao contrário do que é feito atualmente" (Ciências Sociais); "Said, em especial pela gama de exemplos pessoais que ilustram sua posição" (Letras); "Gostei muito do Said, por ele colocar o intelectual em uma posição menos fanática ideologicamente" (Letras); "Said, pois gosto do equilíbrio que ele faz entre Benda e Sartre" (Filosofia).

${ }^{28}$ Isto quer dizer, defender abertamente uma causa política ou ideológica, apresentar um ponto de vista teórico como mais importante que outro por razões acadêmicas ou não acadêmicas, aludir a uma causa, indicando sua posição pessoal sobre o tema, e demais atitudes congêneres.
} 
Dos 32 alunos e alunas que responderam à questão, 19 apontaram para a atitude intelectual, de minha parte, mesclada entre o engajamento e o distanciamento, ao passo que 9 discentes observaram um posicionamento prioritariamente engajado; os outros 4, uma atitude distanciada. ${ }^{29}$ Já quando questionados a respeito da posição que considerariam ser a mais adequada para um professor universitário, 12 indicaram a atitude engajada, 4 a distanciada e 13 ambas as atitudes. ${ }^{30}$

As reflexões dos alunos e alunas sobre esses questionamentos revelaram, por um lado, a julgar pelos relatos, que consegui fugir da armadilha que mais temo como docente: o proselitismo e, por outro, denotaram que obtive êxito (tarefa à qual me imponho com rigor) em apresentar autores e pontos de vista da forma mais imparcial e honesta possível, para que os estudantes chegassem a suas próprias conclusões. Mesmo os discentes que perceberam em mim uma atitude do tipo engajada, justificaram a opção por meio de exemplos que muito me orgulham, vale dizer, o engajamento, nesses casos, foi referido ao ensino, e não a posições político-ideológicas específicas. ${ }^{31}$

${ }^{29}$ Vejamos algumas destas respostas: "Distanciada, pois o professor, dentro do possível, sempre procurou expor todos os pensamentos e opiniões" (Ciências Biológicas); "Uma atitude que tendia mais para o distanciamento, porque nos foi apresentado autores de perspectivas diferentes, sem afirmar qual era a melhor ou pior" (Ciências Sociais); "Como o professor, na maior parte dos casos, assumiu a postura de 'advogado do diabo', diria que foi distanciada" (Ciências Sociais); "Eu acredito que apesar de variar, tendeu mais para a postura engajada, porque o professor se mostrou muito acessível em termos de conteúdo, dúvidas, mas sem prepotência" (Letras); "O professor mostrou-se engajado, pois não apenas expôs as teorias, como também colocou seu posicionamento" (Letras); "Mais engajada, já que sempre apresentou suporte com livros e explicações em sala" (Ciências Sociais); "As duas posições ocorreram, embora com opiniões, estimulou o senso crítico" (Ciências Biológicas); "Penso que as duas posições ocorreram, dependendo do contexto" (Letras); "Acredito que tenhamos tido um pouco de ambas e que o distanciamento foi necessário, em alguns pontos, para termos espaço para formarmos nossas próprias opiniões" (Letras); "Acho que as duas posições ocorreram, pois houve um esforço de certa neutralidade, de mostrar diferentes posicionamentos político-ideológicos" (História).

${ }^{30}$ Alguns exemplos: "Ser engajado, pois professores, como sábios e especialistas, devem se posicionar frente aos acontecimentos como alguém dotado de investidura social e intelectual para o bem de todos" (Letras); "Engajada, já que é importante que o professor se posicione, não significa que haverá influência direta" (Ciências Sociais); "O engajamento, sem dúvida! É a atitude mais apropriada para o professor, porque ele pode estimular reflexões, discussões durante a aula que podem influenciar os alunos a terem uma vida mais crítica e a questionarem suas opiniões" (Ciências Sociais); "Uma posição engajada, afinal a universidade é onde, atualmente, "nasce' a maioria dos intelectuais, e apenas se coloca em prática alguma mudança com o engajamento" (Ciências Biológicas); "Acredito no distanciamento como forma de promover e possibilidade do aluno se afirmar por conta própria, isto é, de formar sua própria opinião sem um 'pré-juízo' da 'autoridade"' (Filosofia); "Mais distanciada, pois enquanto a relação entre professor e aluno for hierárquica, haverá forte influência do primeiro sobre o segundo. $\mathrm{O}$ aluno pode acabar levado a assumir posições que não são próprias" (Letras); "Ambas de modo equilibrado, pois o professor deve ser inclinado aos estudos e reflexão, mas deve se envolver em assuntos nos quais domina, contribuindo com a melhoria da sociedade" (Letras); "Ambas as atitudes. Acredito que seja impossível só ou uma ou outra" (História); "Tendo em vista os aspectos das aulas e os assuntos em pauta (muitas vezes levantados pelos próprios alunos), muitas vezes é quase exigida uma posição por parte do professor, embora o distanciamento seja importante. Por isso, um 'meio termo' entre as duas posições pode ser considerada ideal para o andamento das aulas" (Letras).

${ }^{31}$ Comungo da forte percepção segundo a qual não cabe aos educadores, em todos os níveis de ensino, orientar o caminho a ser percorrido pelos discentes, e tenho verdadeira ojeriza à ideia de me tornar um chefe de seita ou líder do que quer que seja. Espanta-me e me causa espécie a atitude de colegas docentes e pesquisadores que, por exemplo, só aceitam trabalhar com estudantes que tenham o mesmo alinhamento acadêmico e/ou ideológico (autores, escolas de pensamento, posicionamento político etc.) que os seus, ou que estabeleçam esse alinhamento como pré-condição para trabalho conjunto e orientação. A reverência subserviente, preguiçosa e acrítica de \begin{tabular}{|l|l|l|l|l|l|l|}
\hline (C) ETD -Educ. Temat. Digit. & Campinas, SP & v.17 & n.3 & p.673 & set./dez.2015 & ISSN 1676-2592
\end{tabular} 
Outro aspecto que gostaria de destacar, antes de chegar à última parte deste relato, refere-se ao fato de nenhum discente ter apontado o engajamento dos docentes da universidade, em termos de tomada de posição político-ideológica, como um problema, ou mesmo como uma questão. O proselitismo político, com efeito, não configurou preocupação, muito embora seja sabido, sobretudo nos cursos no âmbito das ciências humanas, que ele se faz presente na fala e nas atitudes cotidianas de diversos docentes. A própria dificuldade em separar, no nível semântico, a atividade engajada do docente em termos epistemológicos ou políticos, diz muito sobre o papel marginal que a discussão política ocupa na vida e no dia a dia das novas gerações de estudantes. Tal panorama é reflexo, ao que tudo indica, da crise na qual a universidade se vê inserida atualmente. Ora, se o processo geral e flagrante é o de tornar esse espaço uma arena de disputa de egos e de respectivos currículos Lattes, arbitrada e incentivada pelos órgãos superiores de regulamentação e fomento, como esperar frutos que não correspondam à semeadura em curso?

Finalmente, ao refletirem a respeito da Unicamp e do curso de graduação que escolheram como espaços privilegiados de reflexão intelectual em seu sentido mais amplo, houve uma divisão equilibrada entre aqueles que responderam afirmativa ou negativamente à provocação. Aqueles que optaram pelo primeiro tipo de resposta, acabaram por destacar prioritariamente os aspectos que se referem às possibilidades acadêmicas e de convivência que a Unicamp permite, bem como enfatizaram (em especial os alunos e alunas dos cursos da área de ciências humanas), a natureza questionadora que a caracterizaria.

Com efeito, como se poderá ver pelos dos exemplos selecionados de respostas reproduzidos a seguir, poucas foram as opiniões afirmativas categóricas (dois primeiros exemplos); quase todas as demais continham algum tipo de ressalva (seis relatos subsequentes). ${ }^{32}$

A Unicamp, assim como outras universidades, é um espaço privilegiado para a atividade intelectual, e considero o meu curso (Letras) um espaço também privilegiado e propício para tal atividade. A universidade em geral proporciona a possibilidade do exercício intelectual e legitima esse exercício, dando condições ao indivíduo de externar o seu saber (Letras).

O curso de História tem um caráter que pessoalmente considero inerentemente questionador, principalmente por historicizar, ou seja, problematizar e mapear no tempo, as tradições e as estruturas sociais. Além de ser um espaço institucional marcado pelas mobilizações políticas, o IFCH na Unicamp é um espaço cheio de contradições, marcado pelo pelos pedestais simbólicos do mandarinato acadêmico e pela busca de demandas produtivistas das grandes agências de fomento à pesquisa. Apesar disso, é um espaço privilegiado para a atividade intelectual, inclusive por causa da presença frequente da crítica a essas contradições (História).

Por um lado, acredito que sim, que a Unicamp é um espaço privilegiado para a atividade intelectual. Acredito pela universidade em si ser um espaço para adquirir novos conhecimentos, por ela abranger uma grande diversidade de raças, culturas, ou

diversos intelectuais, ligados ou não à academia, a tradições teóricas cristalizadas serve-me de parâmetro inequívoco daquilo que devo evitar a todo custo.

32 Por motivos de economia de espaço, apenas trechos das respostas foram reproduzidos.

\begin{tabular}{l|l|l|l|l|l|l} 
(C) ETD -Educ. Temat. Digit. & Campinas, SP & v.17 & n.3 & p.673 & set./dez.2015 & ISSN $1676-2592$
\end{tabular}


seja, de poder entrar em contato com um mundo diferente do meu. Mas por outro lado, a minha impressão é que a instituição como um todo está mais preocupada para que nós alunos "reproduzamos" nosso conhecimento na forma prática (Letras).

Sim. A Unicamp, comparando-se a outras universidades, é um espaço privilegiado para a atividade intelectual. Apesar de sofrer da responsabilidade de resultados exemplares de produção, é um local que mantém a valorização, dentro do possível, do pensamento crítico. Em relação ao curso de biologia, a necessidade de produzir (academicamente) é extremamente enfatizada, tornando-se base para o sucesso e possível progresso (Biologia).

Acredito que sim. O curso de Ciências Sociais acaba por exigir um posicionamento perante a realidade. Embora seja um espaço privilegiado para o engajamento intelectual, vejo muitos alunos e até professores que se "desligam" da realidade, produzindo conhecimentos, pesquisas que não têm uma contribuição real na sociedade. A Unicamp como um todo não investe em projetos que auxiliem a população e a comunidade (Ciências Sociais).

Sim. Privilegiado em relação a um espaço que não seja a universidade. Não, se pensarmos na atividade intelectual como processo de adquirir, refletir, produzir e disseminar conhecimento e ideias. Infelizmente o "produzir" se perde cada vez mais e dá lugar ao simples "reproduzir" (Ciências Sociais).

No que concerne ao desenvolvimento científico e possibilidades de atuação, a Unicamp é um espaço privilegiado. Porém, ela reflete o elitismo que permeou a criação da universidade (Biologia).

Se se entender a atividade intelectual como compreensão e análise crítica da realidade dada a partir de embasamento teórico e capital cultural, acredito que o curso de Ciências Sociais da Unicamp pode ser considerado um espaço privilegiado para a atividade intelectual. Mas no quesito de abrir tal análise e torná-la acessível a toda a sociedade, estabelecendo um diálogo do que é promovido a partir da atividade acadêmica com o mundo à sua volta, a Unicamp deixa a desejar (Ciências Sociais).

Universidade que é exemplo do que há de ponta, em termos tecnológicos e científicos, a Unicamp, na condição de espaço público que deveria cumprir o papel atribuído pela sociedade e a vocação que diz representar, isto é, de instância fomentadora da crítica permanente e de desenvolvimento e aprimoramento da sociedade (em particular da comunidade que a cerca), parece falhar flagrantemente em sua missão. Os exemplos de respostas coligidos abaixo apontam para alguns dos processos perversos que marcham a todo vapor nas universidades brasileiras.

A Unicamp, e o curso que escolhi (Biologia), enfrentam a mesma problemática de quase todas as universidades atuais: a de passar de um conhecimento a uma plateia passiva, e não de construí-lo junto aos alunos. A Unicamp poderia ser um espaço para exercer a atividade intelectual, mas tanto docentes quanto alunos, em sua maioria, preocupam-se mais com suas questões individuais (aula, nota, diploma, artigo, laboratório etc.) (Biologia).

O acesso a essa universidade ainda é muito restrito a uma parte privilegiada da sociedade, além de não haver muitos incentivos do governo nos institutos de humanas. Assim, a Unicamp não aproveita o aparato que possui para a produção da atividade intelectual, sendo que, muitas vezes, o conteúdo divulgado fica muito restrito ao público que o produziu, também muito pequeno e seleto (Ciências Sociais) 
Não. O conhecimento que é adquirido aqui por meio dos professores e livros são quase que exclusivamente para a aquisição de conhecimento. As ideias que temos a respeito do que é passado dificilmente são modificadas, poucos são os que têm esse privilégio (Biologia).

A Unicamp e o meu curso de licenciatura em Biologia não são espaços privilegiados para a atividade intelectual. A Unicamp sofre grande pressão para produção científica em quantidade, o que inibe a produção e reflexão mais primorosas. Como exemplo, existem muitos professores que possuem conhecimento aprofundado em suas áreas, mas que são ignorantes em relação a preceitos mais gerais da biologia, que deveriam estar claros para os estudantes (Biologia).

Ainda que eu considere a universidade e, de forma mais acentuada, o curso de Ciências Sociais enquanto ambientes bastante propícios ao engajamento e à atividade intelectual, eles estão longe de atingirem toda sua potencialidade. Falta interação com a comunidade ao entorno, há pouco ou nenhuma produção e discussão acerca dos conflitos e problemas locais; a universidade, além de fechada, se volta para si mesma e não para a sociedade (Ciências Sociais).

O efeito da Unicamp sobre a minha atividade é de não estimular o pensamento intelectual. Reconheço o grande desenvolvimento científico, porém quando se trata de avaliar os efeitos dessa tecnologia, o comprometimento é mínimo (Biologia).

Em relação ao curso que escolhi, Biologia, a universidade não pode ser considerada um espaço privilegiado para a atividade intelectual no seu sentido mais amplo. Isso porque a formação do curso de Biologia progride no sentido de tornar os alunos cada vez mais especialistas em determinada área específica do conhecimento. Ficamos todos cada vez mais distantes de questões universais relacionadas ao homem e à sociedade (Biologia).

Absolutamente não! O IFCH é intransigente demais para considerar o outro ser humano no debate, mas faz do espaço uma praça para o apedrejamento, vendo no outro o inimigo a ser combatido e não um outro a ser considerado. Assim sendo, se posicionar e se engajar por lá é facilmente provocar ser taxado de "reaça", machista, etc. (Ciências Sociais).

Não. Pois o sistema de pesquisa nos quais a universidade se insere visam a produção massiva de conteúdos. O pesquisador é avaliado pelo número de publicações, e não pela relevância que esta possui na sociedade em que está inserida (Biologia).

Acredito que não. Todo o conhecimento que nos é transmitido no curso de Biologia é totalmente empacotado, não abrindo oportunidades para discussões, não havendo espaços para intervenções por parte dos alunos. Sinto que às vezes somos meras esponjas, que estamos ali somente para absorver tudo o que é passado sem questionar (Biologia).

Ainda que eu considere a universidade e, de forma mais acentuada, o curso de Ciências Sociais enquanto ambientes bastante propícios ao engajamento e à atividade intelectual, eles estão longe de atingirem toda sua potencialidade. Falta interação com a comunidade ao entorno, há pouco ou nenhuma produção e discussão acerca dos conflitos e problemas locais; a universidade, além de fechada, se volta para si mesma e não para a sociedade (Ciências Sociais).

Não. O que vejo no Instituto de Biologia, entre graduandos, mestres e doutores, é um interminável preconceito científico, onde apenas as hipóteses empíricas podem ser estudadas (Biologia). 
Não! Quando passei no vestibular tinha uma visão totalmente diferente do que seria a universidade, imaginava que seria um lugar para o exercício do pensamento crítico, mas aprendi que isto não acontece. Quando se expõe uma nova ideia, o mais provável é que ela seja descartada e que o pensador seja punido (Letras).

A Unicamp e o curso de graduação não são espaços privilegiados para a atividade intelectual. Os motivos são múltiplos, porém dentre eles se destacam a inacessibilidade ou a falta de condições de permanência de classes mais baixas, e os critérios cada vez mais exigentes e estapafúrdios de produtividade que professores e alunos têm eu enfrentar (Ciências Sociais).

Podemos recuperar rapidamente alguns dos pontos recorrentes que permearam as respostas: excessiva especialização do conhecimento, que tolhe a criatividade e a reflexão; ênfase na prática científica produtivista, muitas vezes em detrimento à qualidade do ensino; elitismo intelectual; falta de condições de acesso e permanência na universidade; falta de diálogo com a comunidade; preconceito acadêmico, entre outros. Todos esses são processos que não atingem, obviamente, apenas a Unicamp, mas causa preocupação o fato de serem tão marcantes em uma das universidades públicas mais bem estruturadas do país, que ainda oferece aos seus quadros docentes e discentes as melhores condições de trabalho e de vivência. Estaríamos vivendo o crepúsculo derradeiro da (não realizada) ideia humboldtiana de universidade no Brasil? Teria sido premonitório o título dado, já em 1986, por José Artur Gianotti, ao seu livro A Universidade em ritmo de barbárie?

\section{CONSIDERAÇÕES FINAIS E PROVISÓRIAS}

Não gostaria de finalizar este relato com pessimismo. Não há uma resposta categórica para os questionamentos com os quais fechei a seção anterior. Minha intenção, ao refletir sobre os intelectuais e a universidade a partir de uma experiência concreta em sala de aula, é a de provocar o debate e convidar à reflexão aqueles que, como eu, exercem a prática docente no Ensino Superior, sobretudo o público, que é mantido por todos os brasileiros e brasileiras não obstante o fato de apenas uma pequena parcela da população ter acesso a ele. O tom pessimista se refere, portanto, primeiramente, aos fatos e às percepções que acumulei durante anos como observador ${ }^{33} \mathrm{e}$, depois, às impressões que recolhi da experiência de um semestre com estudantes de diversas áreas da Unicamp. Trata-se, ao fim e ao cabo, de um alerta, e não de um apanágio à imobilidade.

A ideia segundo a qual os intelectuais constituem uma camada à parte da sociedade, com status diferenciado e uma missão sempre me pareceu elitista em excesso para ser

\footnotetext{
${ }^{33}$ Nunca irei me esquecer de quando, no decorrer da primeira disciplina que ofereci na Faculdade de Educação da Unicamp, uma aluna do segundo ano do curso de Pedagogia deixou escapar, ao perguntar-me: "Professor, qual é a sua sala no Olimpo"? Sem entender por completo a metáfora, pedi a ela que me explicasse: "A maioria dos professores aqui da Faculdade de Educação se vê como deuses, seres superiores aos alunos, daí que nós chamamos o segundo andar da Faculdade de Olimpo". Depois vim a saber que essa é uma das formas pelas quais os estudantes se referem ao segundo piso da Faculdade, no qual se encontram as salas dos professores.
}

\begin{tabular}{|c|c|c|c|c|c|c}
\hline (C) ETD -Educ. Temat. Digit. & Campinas, SP & v.17 & n.3 & p.673 & set./dez.2015 & ISSN 1676-2592 \\
\hline
\end{tabular}


considerada séria. Por suposto, diferentes indivíduos têm diferentes habilidades e aptidões, o que se reflete em seus respectivos interesses pessoais e profissionais. ${ }^{34}$ Nesse sentido, a ocupação intelectual possui suas particularidades, assim como qualquer outro ofício. Não se trata também, ressalte-se, de uma postura anti-intelectualista. Bem sei que há um fosso entre o intelectual no sentido lato do termo, como aquele que faz das ideias o seu ganha-pão, e o intelectual no sentido específico que a tradição filosófica e sociológica erigiu. Se não considerasse essa premissa como verdadeira, não haveria motivos para oferecer uma disciplina com esta temática, tampouco para redigir este artigo.

Muito me apraz o entendimento de Said em relação à postura intelectual que lhe parecia ser a mais apropriada.

O verdadeiro intelectual é, por contraste, um secular. Apesar de muitos intelectuais desejarem que suas representações expressem coisas superiores ou valores absolutos, a conduta ética e os princípios morais começam com sua atividade no mundo secular - onde tais princípios e conduta se realizam, a quais interesses servem, como se harmonizam com uma ética consistente e universal, como operam a discriminação entre poder e justiça, o que revelam das escolhas e prioridades de cada um. Aqueles deuses que sempre falham acabam exigindo do intelectual uma espécie de certeza absoluta e uma visão total e sem costura da realidade, visão e certeza que reconhecem apenas discípulos ou inimigos (SAID, 2005, p. 120).

Alguns intelectuais, por outro lado (escritores diletantes, romancistas, filósofos, sociólogos, educadores etc.), de fato exerceram de maneira exitosa o papel de maîtres à penser. Não foi pequena nem desimportante a atuação desses indivíduos, para o bem ou para o mal. No atual momento, contudo, estaríamos inseridos, como bem observou Sérgio Paulo Rouanet, em um cenário de crise dos universais, que aponta para o desaparecimento da figura do intelectual como ser generalista; este doravante dá lugar ao especialista universitário: "demógrafos que nunca ouviram falar de Rousseau, cientistas políticos que nunca leram Proust, todos exemplarmente weberianos, e evitando, com o máximo zelo, como aprenderam na universidade, a formar juízos de valor" (ROUANET, 2006, p. 78). De toda forma, seria impossível analisar em toda a sua complexidade os desdobramentos da ação engajada de gerações de homens e mulheres que se colocaram (voluntariamente ou por delegação), tal incumbência.

O que conta realmente, a meu juízo, é o esforço conjunto para o aperfeiçoamento das instituições públicas, bem como para a democratização de suas práticas. Nesse sentido, há que se destacar a vigília permanente que amplos setores da comunidade acadêmica (docentes, estudantes e funcionários) realiza na tentativa de refrear os malignos processos de privatização do espaço público. À resignação poder-se-ia reafirmar (talvez como nunca) a fórmula gramsciana do pessimismo da razão e otimismo da vontade.

\footnotetext{
${ }^{34}$ Interesses e possibilidades que, como sabemos, são muitas vezes limitados pelos condicionantes estruturais da sociedade.
}

\begin{tabular}{l|l|l|l|l|l|l|} 
(C) ETD - Educ. Temat. Digit. & Campinas, SP & v.17 & n.3 & p.673 & set./dez.2015 & ISSN 1676-2592 \\
\hline
\end{tabular}




\section{REFERÊNCIAS}

AGGIO, Alberto. Gramsci: a vitalidade de um pensamento. São Paulo: UNESP, 1998.

ARON, Raymond. O ópio dos intelectuais. Brasília: UnB, 1980.

BENDA, Julien. A traição dos intelectuais. São Paulo: Peixoto Neto, 2007.

BOBBIO, Norberto. Os intelectuais e o poder. São Paulo: UNESP, 1996.

BOTO, Carlota. Traição dos intelectuais. Um tema nosso contemporâneo. Revista USP, São Paulo, SP, v. 1, n. 80, p. 161-171. dez./fev. 2008-2009. Disponível em: 〈 http://goo.gl/4tePbI >. Acesso em: 07 ago. 2015. ISSN 0103-9989.

CHAUÍ, Marilena. Intelectual engajado: uma figura em extinção? In: NOVAES, Adauto (Org.). O silêncio dos intelectuais. São Paulo: Cia das Letras, 2006.

DIAS JUNIOR, Antonio Carlos. A sociologia política de Raymond Aron. 2013. $571 \mathrm{f}$. Tese (Doutorado em Sociologia) - Instituto de Filosofia e Ciências Humanas, Universidade Estadual de Campinas, Campinas, SP, 2013. Disponível em: < http://goo.gl/qQOVqo>. Acesso em: 08 ago. 2015.

FREYRE, Gilberto. Sobrados e mucambos. Rio de Janeiro: José Olympio, 1985.

GIANOTTI, José Arthur. A universidade em ritmo de barbárie. São Paulo: Brasiliense, 1986.

LE GOFF, Jacques Le. Os intelectuais na Idade Média. Rio de Janeiro: José Olympio, 2003.

LEPENIES, Wolf. As três culturas. São Paulo: USP, 1996.

MARX, Karl; ENGELS, Friedrich. A ideologia alemã. São Paulo: Martins Fontes, 2008.

MINTO, Lalo Watanabe. A educação da miséria: particularidade capitalista e educação superior no Brasil. São Paulo: Outras Expressões, 2014.

NOVAES, Adauto (Org.). O silêncio dos intelectuais. São Paulo: Cia das Letras, 2006.

RIBEIRO, Renato Janine. O cientista e o intelectual. In: NOVAES, Adauto (Org.). O silêncio dos intelectuais. São Paulo: Cia das Letras, 2006.

RINGER, Fritz. O declínio dos mandarins alemães. São Paulo: Editora da USP, 2000.

\begin{tabular}{l|l|l|l|l|l|l} 
(C) ETD -Educ. Temat. Digit. & Campinas, SP & v.17 & n.3 & p.673 & set./dez.2015 & ISSN 1676-2592
\end{tabular}


ROUANET, Sérgio Paulo. A crise dos universais. In: NOVAES, Adauto (Org.). O silêncio dos intelectuais. São Paulo: Cia das Letras, 2006.

SAID, Edward. Representações do intelectual. São Paulo: Cia das Letras, 2005.

SARTRE, Jean-Paul. Em defesa dos intelectuais. São Paulo: Ática, 1994.

SIRINELLI, Jean-François. Sartre, um intelectual engajado. In: NOVAES, Adauto (Org.). O silêncio dos intelectuais. São Paulo: Cia das Letras, 2006.

SILVA, Franklin Leopoldo. O Imperativo ético de Sartre. In: NOVAES, Adauto (Org.). O silêncio dos intelectuais. São Paulo: Cia das Letras, 2006.

STEINER, João; MALNIC, Gerhard. (Org.). Ensino Superior: conceito e dinâmica. São Paulo: Editora da USP, 2006.

TOCQUEVILLE, Alexis. L’ancien régime et la révolution. Paris: Gallimard, 1967.

WEBER, Max. A ética protestante e o espírito do capitalismo. São Paulo: Pioneira, 2001.

WEBER, Max. Ciência e política: duas vocações. São Paulo: Cultrix, 1972.

\section{Como citar este documento:}

DIAS JUNIOR, Antonio Carlos. Intelectuais e universidade percepções sociológicas a partir de uma experiência pedagógica. ETD - Educação Temática Digital, Campinas, SP, v. 17, n. 3, nov. 2015. ISSN 1676-2592.

Disponível em: 〈http://periodicos.sbu.unicamp.br/ojs/index.php/etd/article/view/8639482〉. Acesso em: 15 dez. 2015. 